\title{
Acute and Chronic Toxicity of an Aqueous Fraction of the Stem Bark of Stryphnodendron adstringens (Barbatimão) in Rodents
}

\author{
Marco Antonio Costa, ${ }^{1}$ João Carlos Palazzo de Mello, ${ }^{1,2}$ \\ Edílson Nobuyoshi Kaneshima, ${ }^{3}$ Tânia Ueda-Nakamura, ${ }^{1,3}$ \\ Benedito Prado Dias Filho, ${ }^{1,3}$ Elisabeth Aparecida Audi, ${ }^{1,4}$ and Celso Vataru Nakamura ${ }^{1,3,5}$ \\ ${ }^{1}$ Programa de Pós-Graduação em Ciências Farmacêuticas, Universidade Estadual de Maringá, Avenida Colombo 5790, \\ 87020-900 Maringá, PR, Brazil \\ ${ }^{2}$ Departamento de Farmácia, Universidade Estadual de Maringá, Avenida Colombo 5790, 87020-900 Maringá, PR, Brazil \\ ${ }^{3}$ Departamento de Ciências Básicas da Saúde, Universidade Estadual de Maringá, Avenida Colombo 5790, \\ 87020-900 Maringá, PR, Brazil \\ ${ }^{4}$ Departamento de Farmacologia e Terapêutica, Universidade Estadual de Maringá, Avenida Colombo 5790, \\ 87020-900 Maringá, PR, Brazil \\ ${ }^{5}$ Laboratório de Inovação Tecnológica no Desenvolvimento de Fármacos e Cosméticos, Avenida Colombo 5790, \\ Bloco B08, 87020-900 Maringá, PR, Brazil
}

Correspondence should be addressed to Celso Vataru Nakamura; cvnakamura@gmail.com

Received 4 April 2013; Revised 25 June 2013; Accepted 25 June 2013

Academic Editor: Ulysses Paulino Albuquerque

Copyright (c) 2013 Marco Antonio Costa et al. This is an open access article distributed under the Creative Commons Attribution License, which permits unrestricted use, distribution, and reproduction in any medium, provided the original work is properly cited.

Stryphnodendron adstringens has a high tannin content and is used as an antiseptic and antimicrobial and in the treatment of leucorrhea, gonorrhea, wound healing, and gastritis. The present study evaluated the toxic effects of the heptamer prodelphinidin (F2) from the stem bark of $S$. adstringens in rodents. In the acute toxicity test, the mice that received oral doses exhibited reversible effects, with an $\mathrm{LD}_{50}$ of $3.015 \mathrm{mg} \cdot \mathrm{kg}^{-1}$. In the chronic toxicity test at 90 days, Wistar rats were treated with different doses of F2 (10, 100 , and $\left.200 \mathrm{mg} \cdot \mathrm{kg}^{-1}\right)$. In the biochemical, hematological, and histopathological examinations and open-field test, the different dose groups did not exhibit significant differences compared with controls. The present results indicate that F2 from the stem bark of $S$. adstringens caused no toxicity with acute and chronic oral treatment in rodents at the doses administered.

\section{Introduction}

The bioactivity of various compounds in medicinal plants has been assessed. These compounds are isolated and analyzed to determine biological activity, mechanisms of action, and toxicity $[1,2]$. The genus Stryphnodendron sp belongs to the family Fabaceae (native savanna), approximately 48 species of which have been identified, including Stryphnodendron adstringens (Mart.) Coville (known as "barbatimão"). This species is found in the central savannah region of Brazil [3-5]. This plant is popularly used as an antiseptic and antimicrobial and in the treatment of leucorrhea, gonorrhea, gastritis, diarrhea, bleeding, and wound healing [6-9]. Scientific research has shown that it has antiulcerogenic potential, antiprotozoan activity, anti-inflammatory effects, antimicrobial activity, and wound healing effects $[6,10-18]$.

The bark of $S$. adstringens is rich in proanthocyanidin polymers, including several flavan-3-ols, such as prodelphinidins and prorobinetinidins [19-22]. The chemical composition of prodelphinidin (F2) has been partially defined as a heptamer compound [16].

The toxicity of $S$. adstringens was the subject of a study by Rebecca et al. [23, 24]. The crude extract of stem bark was administered at high doses in mice and tested in liver mitochondria, showing signs of liver toxicity. Other studies have been conducted with other parts of the plant $[25,26]$. 
Studies by De Sousa et al. [27] and Costa et al. [28] showed that $S$. adstringens had no genotoxic effects in Drosophila melanogaster or micronuclei (bone marrow) and Artemia salina tests in mice, respectively.

Thus, considering the wide use of this plant and that few studies have been conducted to determine the toxicological profile of $S$. adstringens, the present study sought to obtain more information about toxicity at therapeutic doses.

\section{Materials and Methods}

2.1. Plant Material. Stem bark from Stryphnodendron adstringens was collected in São Jerônimo da Serra, Paraná, Brazil (S23 $43^{\prime} 7.8^{\prime \prime}$, W50 $45^{\prime} 23.5^{\prime \prime}$; altitude $926 \mathrm{~m}$ ), in March 2008. A voucher herbarium specimen was deposited at the Universidade Estadual de Maringá (no. HUM 14321).

2.2. Aqueous Fraction. The bark was dried at room temperature and then pulverized. The crude extract was obtained by turboextraction of the bark at 1,000 $\times$ g with $70 \%$ acetone in water for $15 \mathrm{~min}$. The organic solvent was eliminated by rotavapor and lyophilized to yield a crude extract (F1; $300 \mathrm{~g})$. F1 $(50 \mathrm{~g})$ was suspended in water $(500 \mathrm{~mL})$ and partitioned with ethyl acetate $(500 \mathrm{~mL} ; 1: 1)$ to obtain a proanthocyanidin polymer-rich fraction (aqueous fraction; F2; $35 \mathrm{~g}$ ).

2.3. Animals. Adult Wistar rats (90 days old), weighing 230$240 \mathrm{~g}$ (female) and 355-365 g (male), and Swiss mice (60 days old), weighing 35-45 g (female) and 45-60 g (male), were used and housed in groups of five per cage, with food and water freely available. The animals were maintained on a $12 \mathrm{~h} / 12 \mathrm{~h}$ light/dark cycle under controlled temperature $(22 \pm$ $\left.1^{\circ} \mathrm{C}\right)$. The protocol was approved by the Ethical Committee of the State University of Maringá (Approval no. 026/2009).

2.4. Toxicity Studies. The toxicity studies were performed according to the Brazilian National Health Surveillance Agency (ANVISA) [29-32].

2.4.1. Acute Toxicity Study in Mice. Swiss mice were divided into seven groups, with 10 animals per group (five males and five females). Six groups were orally treated by gavage with different doses of F2 (500, 1,000, 2,000, 3,000, 4,000, and $\left.5,000 \mathrm{mg} \cdot \mathrm{kg}^{-1}\right)$. One group that received distilled water was included as a negative control. The volume administered by gavage in the mice was approximately $0.3 \mathrm{~mL}$ per animal. Water and food were freely available to the animals. The general behavior and number of survivors were observed at $5 \mathrm{~min}, 15 \mathrm{~min}, 30 \mathrm{~min}, 1 \mathrm{~h}, 2 \mathrm{~h}, 4 \mathrm{~h}$, and $24 \mathrm{~h}$ and daily thereafter until day 14. Toxicological effects were assessed, including changes in locomotion, respiration, piloerection, diarrhea, drooling, altered muscle tone, hypnosis, convulsions, hyperexcitability, writhing (abdominal constrictions), and mortality (which is expressed as the median lethal dose $\left.\left[\mathrm{LD}_{50}\right]\right)[33]$. From the 24th hour until day 14 , the weights of the animals were recorded.

At the end of this period, all of the animals were sacrificed. The kidneys, heart, lungs, spleen, and liver were removed, weighed, and evaluated for macroscopic abnormalities. When changes were observed in the autopsies, further histological examination of the organs was performed.

2.4.2. Repeated-Dose Oral Toxicity Study in Rats. Wistar rats were divided into four groups (11 males and 11 females). One group served as the control and received only water. The other groups received F2 of S. adstringens (10, 100, or $200 \mathrm{mg} \cdot \mathrm{kg}^{-1}$ ) suspended in water and administered orally by gavage daily for 90 days. The volume administered by gavage in the rats was approximately $0.5 \mathrm{~mL}$ per animal. The choice of the doses was based on the estimated oral dose in popular use $\left(10 \mathrm{mg} \cdot \mathrm{kg}^{-1}\right)$ [34] and 10- and 20-times the effective dose $[29,30]$.

All of the animals received food and water ad libitum during the treatment. They were observed daily with regard to behavior and weighed weekly. At the end of the 90-day period, the animals were deprived of food for $15 \mathrm{~h}$ and then sacrificed. Their blood was collected for biochemical and hematological examination. The organs were carefully dissected and removed for weighing, macroscopic examination, and histopathological analysis.

Blood Analysis. Biochemical analyses were performed to determine glucose, aspartate aminotransferase (AST), alanine aminotransferase (ALT), alkaline phosphatase (ALP), total protein, creatinine, uric acid, blood urea nitrogen (BUN), triglycerides, total cholesterol, $\gamma$-glutamyltransferase ( $\gamma$-GT), bilirubin, sodium, and potassium. These were evaluated using the Dimension RXL Max system (Siemens).

Hematological analyses were performed using the automatic counter Pentra 60 ABX (ABX Diagnostics) to evaluate the following parameters: erythrocyte count (red blood cells (RBCs)), hemoglobin, hematocrit, mean corpuscular volume (MCV), mean corpuscular hemoglobin (MCH), mean corpuscular hemoglobin concentration (MCHC), platelet count, and leucocyte count (white blood cells (WBCs)). Differential WBC counts (nonsegmented neutrophils, segmented neutrophils, basophils, eosinophils, lymphocytes, and monocytes) were made using a glass-slide method. Immediately after collection, blood smears were air-dried and stained with Leishman's stain. One hundred cells were randomly counted in each smear, and the percentage of each type was calculated. Any morphological change in the blood cells was noted.

Organ Weights and Histopathological Analyses. The organs (thymus, esophagus, stomach, duodenum, lung, heart, kidneys, liver, spleen, adrenals, and sex organs) of all of the animals were examined macroscopically. The positions, shapes, sizes, and colors of the internal organs were visually observed for signs of macroscopic abnormalities. The organs were weighed and fixed in Bouin's fixative and preserved in 70\% ethanol. For the $200 \mathrm{mg} \cdot \mathrm{kg}^{-1}$ dose of F2 and controls, tissue slides were prepared and stained with hematoxylin and eosin for microscopic examination.

Open-Field Test (OFT). Locomotor behavior was assessed on day 86 of treatment in the open-field test. Each animal was placed in a round wooden arena $(70 \mathrm{~cm}$ diameter) 
TABLE 1: Acute toxicity of F2 of Stryphnodendron adstringens administered orally in mice.

\begin{tabular}{|c|c|c|c|c|c|c|c|c|c|c|}
\hline \multirow{2}{*}{$\begin{array}{l}\mathrm{F} 2 \mathrm{~S} . \\
\text { adstringens } \\
\text { dose } \\
\left(\mathrm{mg} \cdot \mathrm{kg}^{-1}\right)\end{array}$} & \multicolumn{10}{|c|}{ Observed changes } \\
\hline & $\begin{array}{l}\text { No. of } \\
\text { deaths }\end{array}$ & Diarrhea & Piloerection & Hypoactivity & Hyperventilation & Ptosis & Hypothermia & $\begin{array}{c}\text { Motor } \\
\text { impairment }\end{array}$ & Catatonia & $\begin{array}{c}\text { Hypnosis/ } \\
\text { sedation }\end{array}$ \\
\hline Control & 0 & No & No & No & No & No & No & No & No & No \\
\hline 500 & 0 & No & No & No & No & No & No & No & No & No \\
\hline 1,000 & 0 & No & No & No & No & No & No & No & No & No \\
\hline 2,000 & 2 & $\begin{array}{l}\text { Reversible } \\
\text { after } 8 \mathrm{~h} \\
(2)\end{array}$ & $\begin{array}{c}\text { Reversible } \\
\text { after } 72 \mathrm{~h} \\
(5)\end{array}$ & No & No & No & No & No & No & No \\
\hline 3,000 & 7 & $\begin{array}{l}\text { Reversible } \\
\text { after } 8 \mathrm{~h} \\
(1)\end{array}$ & $\begin{array}{l}\text { Reversible } \\
\text { after } 7 \mathrm{~d} \\
(6)\end{array}$ & $\begin{array}{l}\text { Reversible } \\
\text { after } 48 \mathrm{~h} \\
\quad(4)\end{array}$ & $\begin{array}{c}\text { Reversible after } \\
48 \mathrm{~h} \\
(2)\end{array}$ & $\begin{array}{l}\text { Reversible } \\
\text { after } 48 \mathrm{~h} \\
(1)\end{array}$ & $\begin{array}{l}\text { Reversible } \\
\text { after } 48 \mathrm{~h} \\
\text { (1) }\end{array}$ & $\begin{array}{l}\text { Reversible } \\
\text { after } 48 \mathrm{~h} \\
\text { (1) }\end{array}$ & No & No \\
\hline 4,000 & 9 & $\begin{array}{l}\text { Reversible } \\
\text { after } 8 \mathrm{~h} \\
(6)\end{array}$ & $\begin{array}{c}\text { Reversible } \\
\text { after } 7 \mathrm{~d} \\
(12)\end{array}$ & $\begin{array}{l}\text { Reversible } \\
\text { after } 48 \mathrm{~h} \\
\quad(9)\end{array}$ & $\begin{array}{c}\text { Reversible after } \\
4 \mathrm{~h} \\
(2)\end{array}$ & No & $\begin{array}{l}\text { Reversible } \\
\text { after } 48 \mathrm{~h} \\
\quad(4)\end{array}$ & No & $\begin{array}{l}\text { Reversible } \\
\text { after } 1 \mathrm{~h} \\
\text { (1) }\end{array}$ & No \\
\hline 5,000 & 11 & $\begin{array}{l}\text { Reversible } \\
\text { after } 48 \mathrm{~h} \\
(6)\end{array}$ & $\begin{array}{c}\text { Reversible } \\
\text { after at } 14 \mathrm{~d} \\
(10)\end{array}$ & $\begin{array}{l}\text { Reversible } \\
\text { after } 48 \mathrm{~h} \\
\quad(5)\end{array}$ & $\begin{array}{c}\text { Reversible after } \\
12 \mathrm{~h} \\
(8)\end{array}$ & $\begin{array}{c}\text { Reversible } \\
\text { after } 48 \mathrm{~h} \\
(1)\end{array}$ & $\begin{array}{c}\text { Reversible } \\
\text { after } 48 \mathrm{~h} \\
(4)\end{array}$ & $\begin{array}{l}\text { Reversible } \\
\text { after } 1 \mathrm{~h} \\
(1)\end{array}$ & No & $\begin{array}{c}\text { Reversible } \\
\text { after } 12 \mathrm{~h} \\
(1)\end{array}$ \\
\hline
\end{tabular}

No: no toxic symptoms observed. The numbers in parentheses indicate the number of animals that showed the changes. The mice were observed daily for signs of toxicity (behavioral changes and mortality) for 14 days.

with $30 \mathrm{~cm}$ high walls. Luminosity at the center of the open field was 60 lux during a 5-min period. Rearing, self-cleaning, urination, the number of fecal pellets, and locomotion were recorded [35]. For the evaluation of locomotion, the total distance traveled was analyzed using a video tracking system (Ethovision).

2.5. Statistical Analyses. The results are expressed as mean \pm standard deviation (SD). The data were analyzed using Statistica 8.0 software. The statistical analyses were performed using one-way analysis of variance (ANOVA) followed by the Dunnett post hoc test. When the variance was not constant, the nonparametric Kruskal-Wallis test was performed to determine significant differences. The histopathological results were analyzed using Fisher's exact test. Differences were considered significant at $P \leq 0.05$.

\section{Results}

3.1. Acute Toxicity Study in Mice. The effects are summarized in Table 1 . The doses of 500 and $1,000 \mathrm{mg} \cdot \mathrm{kg}^{-1}$ showed no signs of toxicity. Only the $2,000 \mathrm{mg} \cdot \mathrm{kg}^{-1}$ dose caused signs of toxicity, beginning with diarrhea and piloerection. At doses of 3,000-5,000 mg. $\mathrm{kg}^{-1}$, hypoactivity, hyperventilation, ptosis, hypothermia, motor impairment, sedation, and catatonia were observed, all of which were reversible after $48 \mathrm{~h}$. Death occurred in the groups that received 2,000-5,000 $\mathrm{mg} \cdot \mathrm{kg}^{-1}$, resulting in an $\mathrm{LD}_{50}$ of $3,015 \mathrm{mg} \cdot \mathrm{kg}^{-1}$. All of the groups had lower body weights in the first $24 \mathrm{~h}$. After 7 days, however, body weights recovered (Figure 1). With regard to the weights of the organs, only the liver showed a decrease at doses of 4,000 and 5,000 mg. $\mathrm{kg}^{-1}$ (Table 2). In the macroscopic and histopathological analyses, no changes were observed at lower doses. Only liver tissue damage was observed at the $5,000 \mathrm{mg} \cdot \mathrm{kg}^{-1}$ dose.

\subsection{Repeated-Dose Oral Toxicity Study in Rats}

3.2.1. Behavior and Body Weight Gain. During treatment, no signs of toxicity were observed in the animals. Body weight gain as a function of time is shown in Figures 2 and 3. All of the groups showed weight gain compared with their initial weight, with the exception of the $100 \mathrm{mg} \cdot \mathrm{kg}^{-1}$ dose in females. Furthermore, the doses of 100 and $200 \mathrm{mg} \cdot \mathrm{kg}^{-1}$ in males and $100 \mathrm{mg} \cdot \mathrm{kg}^{-1}$ in females caused less weight gain compared with controls (Figures 2 and 3; Table 3).

3.2.2. Biochemical Analyses. The effects of F2 of S. adstringens on biochemical profiles showed specific changes (Table 4). In male rats, some parameters were significantly increased compared with the control group, including potassium $\left(10.7 \pm 2.4 \mathrm{mEq} \cdot \mathrm{L}^{-1}\right.$ at $\left.100 \mathrm{mg} \cdot \mathrm{kg}^{-1}\right)$, uric acid $(2.7 \pm 1.1$ and $2.0 \pm 0.8 \mathrm{mg} \cdot \mathrm{dL}^{-1}$ at 100 and $200 \mathrm{mg} \cdot \mathrm{kg}^{-1}$, resp.), and AST $\left(186.0 \pm 47.0 \mathrm{U} \cdot \mathrm{L}^{-1}\right.$ at $\left.100 \mathrm{mg} \cdot \mathrm{kg}^{-1}\right)$. Other parameters were significantly decreased, including triglyceride $\left(85.5 \pm 28.3 \mathrm{mg} \cdot \mathrm{dL}^{-1}\right.$ at $\left.200 \mathrm{mg} \cdot \mathrm{kg}^{-1}\right)$ and creatinine $(0.4 \pm$ $0.1 \mathrm{mg} \cdot \mathrm{dL}^{-1}$ at $\left.100 \mathrm{mg} \cdot \mathrm{kg}^{-1}\right)$. In female rats, only triglycerides $\left(58.9 \pm 12.5\right.$ and $72.7 \pm 21.3 \mathrm{mg} \cdot \mathrm{dL}^{-1}$ at 100 and $200 \mathrm{mg} \cdot \mathrm{kg}^{-1}$, resp.) were significantly decreased compared with the control group.

3.2.3. Haematological Analyses. The effects of F2 of S. adstringens on hematological parameters showed specific changes but only in male rats (Table 5). Significant differences from the control groups were found, including decreased $\mathrm{MCH}$ $(20.0 \pm 0.4,19.9 \pm 0.5$, and $20.0 \pm 0.4 \mathrm{pg}$ at 10, 100, 


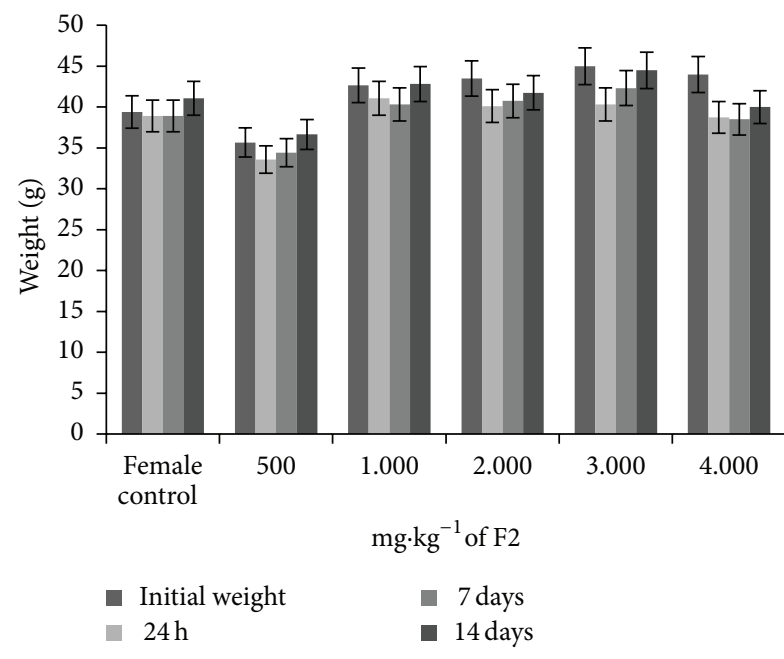

(a)

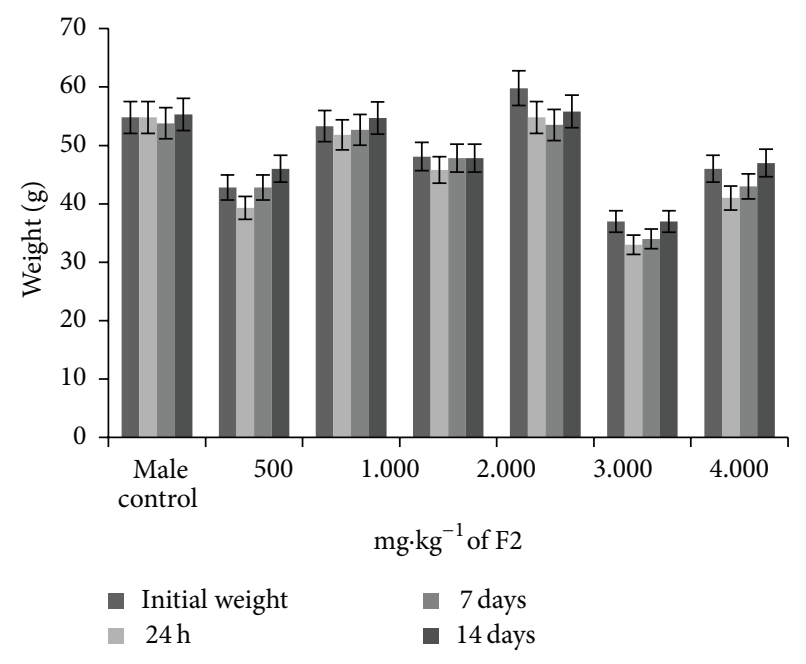

(b)

Figure 1: Body weight gain (g) in female mice (a) and male mice (b) treated orally with 500, 1,000, 2,000, 3,000, 4,000, and 5,000 mg.kg ${ }^{-1}$ F2 in the acute toxicity study.

TABLE 2: Effect of F2 of Stryphnodendron adstringens on the weights of organs of mice.

\begin{tabular}{|c|c|c|c|c|c|c|c|}
\hline \multirow{2}{*}{ Organs } & \multicolumn{7}{|c|}{ F2 S. adstringens $\left(\mathrm{mg} \cdot \mathrm{kg}^{-1}\right)$} \\
\hline & Control & 500 & 1,000 & 2,000 & 3,000 & 4,000 & 5,000 \\
\hline \multicolumn{8}{|l|}{ Male } \\
\hline Liver & $3.27 \pm 0.4$ & $2.57 \pm 0.3$ & $2.87 \pm 0.2$ & $2.75 \pm 0.3$ & $2.58 \pm 0.2$ & $2.32 \pm 0.3^{*}$ & $2.45 \pm 0.6^{*}$ \\
\hline Spleen & $0.31 \pm 0.04$ & $0.24 \pm 0.02$ & $0.27 \pm 0.06$ & $0.30 \pm 0.07$ & $0.20 \pm 0.05$ & $0.20 \pm 0.03$ & $0.20 \pm 0.06$ \\
\hline Lungs & $0.48 \pm 0.01$ & $0.35 \pm 0.03$ & $0.40 \pm 0.04$ & $0.35 \pm 0.04$ & $0.46 \pm 0.11$ & $0.39 \pm 0.06$ & $0.46 \pm 0.16$ \\
\hline Heart & $0.31 \pm 0.03$ & $0.25 \pm 0.04$ & $0.27 \pm 0.04$ & $0.28 \pm 0.04$ & $0.34 \pm 0.05$ & $0.29 \pm 0.07$ & $0.32 \pm 0.04$ \\
\hline Kidneys & $0.95 \pm 0.09$ & $0.67 \pm 0.05$ & $0.82 \pm 0.05$ & $0.70 \pm 0.09$ & $0.81 \pm 0.06$ & $0.64 \pm 0.10$ & $0.72 \pm 0.12$ \\
\hline \multicolumn{8}{|l|}{ Female } \\
\hline Liver & $2.22 \pm 0.3$ & $1.94 \pm 0.2$ & $2.04 \pm 0.3$ & $1.93 \pm 0.3$ & $1.98 \pm 0.5$ & $1.92 \pm 0.4^{*}$ & $1.68 \pm 0.2^{*}$ \\
\hline Spleen & $0.25 \pm 0.04$ & $0.20 \pm 0.06$ & $0.28 \pm 0.06$ & $0.29 \pm 0.09$ & $0.24 \pm 0.07$ & $0.26 \pm 0.08$ & $0.19 \pm 0.03$ \\
\hline Lungs & $0.38 \pm 0.07$ & $0.32 \pm 0.06$ & $0.33 \pm 0.04$ & $0.36 \pm 0.07$ & $0.43 \pm 0.15$ & $0.50 \pm 0.15$ & $0.47 \pm 0.14$ \\
\hline Heart & $0.20 \pm 0.04$ & $0.17 \pm 0.04$ & $0.21 \pm 0.06$ & $0.24 \pm 0.03$ & $0.25 \pm 0.07$ & $0.25 \pm 0.06$ & $0.19 \pm 0.03$ \\
\hline Kidneys & $0.51 \pm 0.06$ & $0.44 \pm 0.08$ & $0.49 \pm 0.03$ & $0.55 \pm 0.07$ & $0.52 \pm 0.07$ & $0.51 \pm 0.09$ & $0.49 \pm 0.03$ \\
\hline
\end{tabular}

Values expressed as mean \pm DP (standard deviation). ANOVA or Kruskal-Wallis tests. ${ }^{*} P<0.05$ compared to control.

TABLE 3: Percentage of weight gain in the animals after 90 days of treatment with the aqueous fraction (F2) of S. adstringens.

\begin{tabular}{|c|c|c|}
\hline \multirow{2}{*}{ Groups } & \multicolumn{2}{|c|}{ Weight gain (\%) } \\
\hline & Male & Female \\
\hline Control & $26.2 \pm 3.3$ & $20.8 \pm 4.3$ \\
\hline $10 \mathrm{mg} \cdot \mathrm{kg}^{-1}$ & $22.7 \pm 6.2$ & $15.5 \pm 4.2$ \\
\hline $100 \mathrm{mg} \cdot \mathrm{kg}^{-1}$ & $18.4 \pm 6.9^{*}$ & $12.8 \pm 5.5^{*}$ \\
\hline $200 \mathrm{mg} \cdot \mathrm{kg}^{-1}$ & $15.2 \pm 5.6^{*}$ & $14.8 \pm 3.9$ \\
\hline
\end{tabular}

${ }^{*}$ Values are mean \pm S.E.M. ANOVA test. ${ }^{*} P<0.05$ compared to the control group.

and $200 \mathrm{mg} \cdot \mathrm{kg}^{-1}$, resp.), decreased MCHC $(35.1 \pm 0.3 \%$ at $\left.100 \mathrm{mg} \cdot \mathrm{kg}^{-1}\right)$, and increased platelet counts $(929 \pm 108$ and $961 \pm 105 \times 10^{3} \mathrm{~mm}^{-3}$ at 10 and $100 \mathrm{mg} \cdot \mathrm{kg}^{-1}$, resp.). No significant differences were observed in female rats compared with the control group.

3.2.4. Organ Weights and Histopathological Analyses. No macroscopic alterations, differences in relative body weight, or histopathological parameters were observed compared with controls.

3.2.5. Open-Field Test. Locomotion (Figure 4), rearing, urination, the number of fecal pellets, and self-cleaning behavior were not significantly different between the treatment groups and controls.

\section{Discussion}

The indiscriminate use of $S$. adstringens without considering possible toxicity or efficacy can lead to serious 


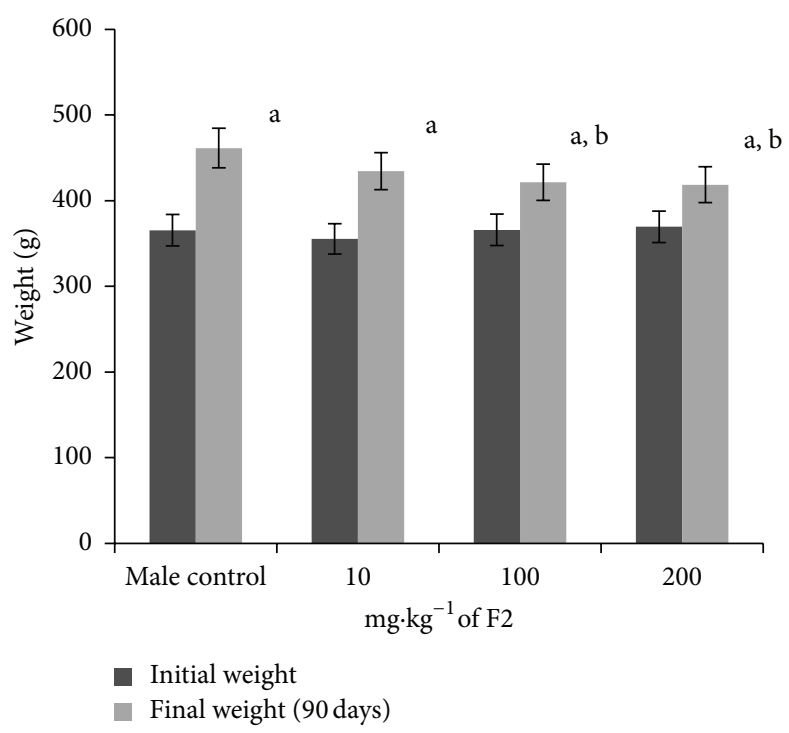

(a)

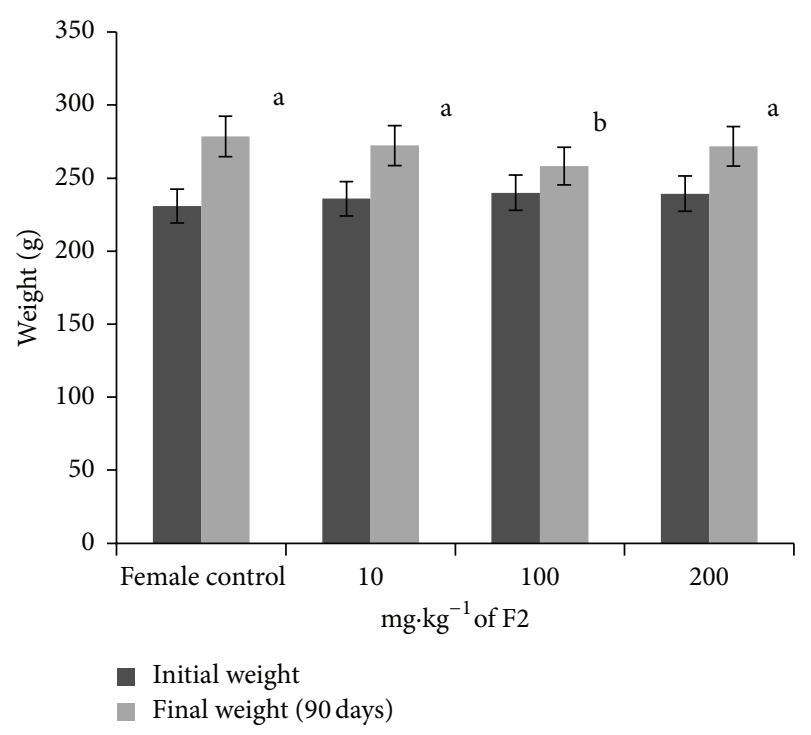

(b)

FIGURE 2: Body weight gain (g) in male rats (a) and female rats (b) treated orally for 90 days with F2 of S. adstringens (10, 100, and 200 mg.kg ${ }^{-1}$ ) and controls. ${ }^{\mathrm{a}} \mathrm{P}<0.05$, compared with initial values; ${ }^{\mathrm{b}} \mathrm{P}<0.05$, compared with control values (ANOVA).

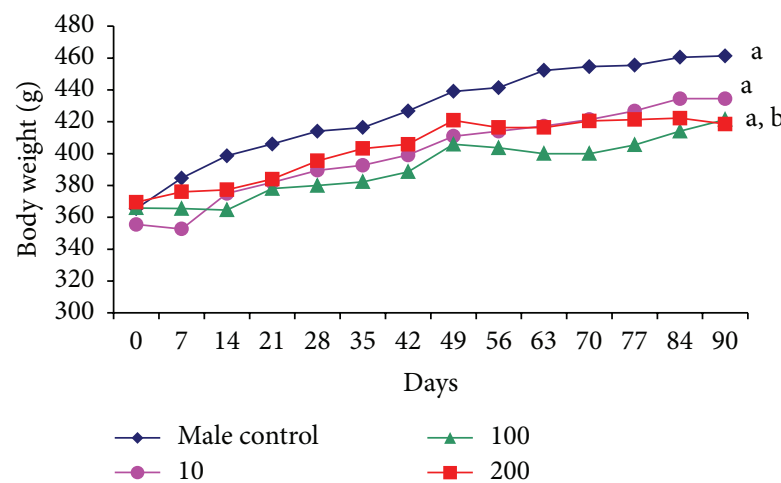

(a)

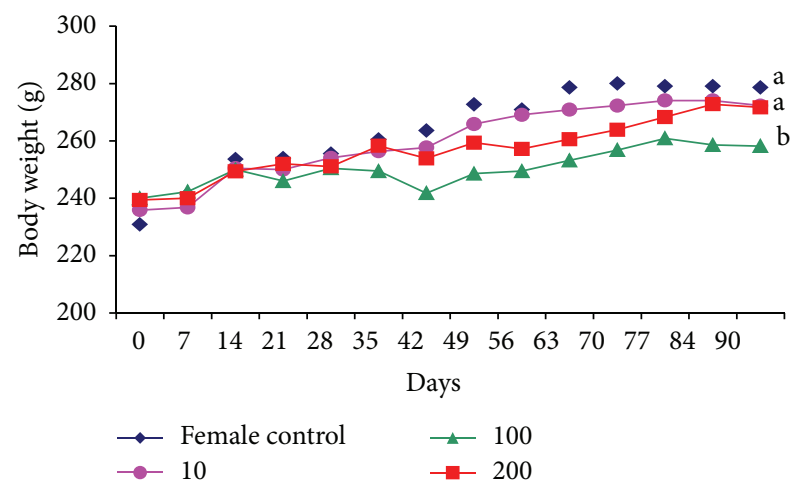

(b)

Figure 3: Body weight (g) in male rats (a) and female rats (b) treated orally for 90 days with F2 of S. adstringens $\left(10 \mathrm{mg} \cdot \mathrm{kg}^{-1} \cdot, 100 \mathrm{mg} \cdot \mathrm{kg}^{-1} \boldsymbol{\Lambda}\right.$, and $\left.200 \mathrm{mg} \cdot \mathrm{kg}^{-1} \mathbf{m}\right)$ and controls $(\downarrow) .{ }^{a} P<0.05$, compared with initial values; ${ }^{\mathrm{b}} P<0.05$, compared with controls (ANOVA).

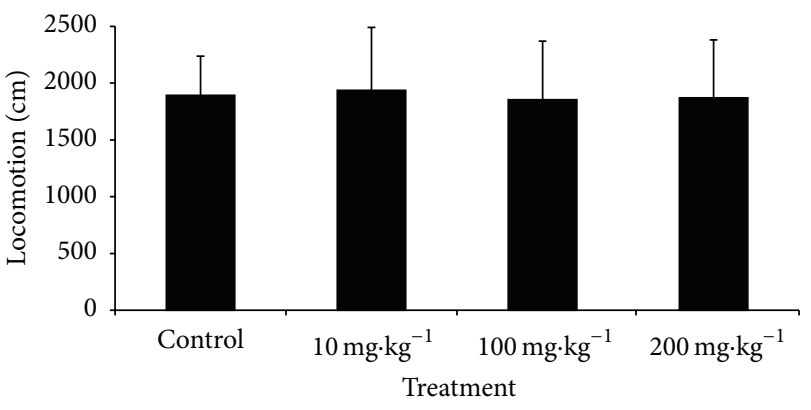

Figure 4: Open-field test results. The figure shows locomotion in rats that orally received F2 of Stryphnodendron adstringens at day 86 of treatment. The data are expressed as mean \pm SEM. ${ }^{*} P<0.05$, compared with control group (ANOVA). health risks. The proanthocyanidin polymer-rich fraction (heptamer compound) of the stem bark of S. adstringens (F2) offers possible advantages, including antifungal activity against Candida spp., especially C. albicans [16]. Vulvovaginal candidiasis is one of the most frequent pathologies observed in daily gynecology practice. Alternative herbal treatments may be less costly and lead to greater adherence to treatment, thus improving the patients quality of life [36-38].

The results of the acute toxicity study indicated that the toxicity of F2 from the stem bark of $S$. adstringens is low (Tables 1 and 2). Some signs of toxicity were observed, which increased progressively with increasing dose but were quickly reversible. No significant changes in organ weight or macroscopic and histological parameters were observed compared with the control group. 
TABLE 4: Biochemical parameters in male and female rats orally treated with F2 of S. adstringens for 90 days.

\begin{tabular}{|c|c|c|c|c|}
\hline \multirow{2}{*}{ Parameters } & \multirow{2}{*}{ Controls } & \multicolumn{3}{|c|}{$\mathrm{F} 2\left(\mathrm{mg} \cdot \mathrm{kg}^{-1}\right)$} \\
\hline & & 10 & 100 & 200 \\
\hline \multicolumn{5}{|c|}{ Male } \\
\hline Sodium $\left(\mathrm{mEq} \cdot \mathrm{L}^{-1}\right)$ & $142.2 \pm 5.0$ & $144.5 \pm 1.6$ & $142.1 \pm 3.3$ & $141.7 \pm 2.7$ \\
\hline Potassium $\left(\mathrm{mEq} \cdot \mathrm{L}^{-1}\right)$ & $6.3 \pm 0.4$ & $7.3 \pm 0.4$ & $10.7 \pm 2.4^{*}$ & $7.5 \pm 1.2$ \\
\hline Glucose $\left(\mathrm{mg} \cdot \mathrm{dL}^{-1}\right)$ & $122.6 \pm 11.6$ & $127.9 \pm 12.5$ & $129.4 \pm 15.5$ & $123.4 \pm 29.0$ \\
\hline Triglyceride $\left(\mathrm{mg} \cdot \mathrm{dL}^{-1}\right)$ & $119.9 \pm 23.4$ & $134.5 \pm 23.4$ & $95.7 \pm 23.5$ & $85.5 \pm 28.3^{*}$ \\
\hline Cholesterol $\left(\mathrm{mg} \cdot \mathrm{dL}^{-1}\right)$ & $99.3 \pm 13.9$ & $104.5 \pm 19.1$ & $97.1 \pm 10.2$ & $92.7 \pm 21.1$ \\
\hline Uric acid $\left(\mathrm{mg} \cdot \mathrm{dL}^{-1}\right)$ & $1.2 \pm 0.2$ & $1.5 \pm 0.2$ & $2.7 \pm 1.1^{*}$ & $2.0 \pm 0.8^{*}$ \\
\hline $\operatorname{ALP}\left(U \cdot L^{-1}\right)$ & $76.0 \pm 18.3$ & $68.4 \pm 9.6$ & $84.0 \pm 15.8$ & $89.2 \pm 13.0$ \\
\hline $\operatorname{AST}\left(\mathrm{U} \cdot \mathrm{L}^{-1}\right)$ & $106.7 \pm 19.5$ & $148.6 \pm 26.3$ & $186.0 \pm 47.0^{*}$ & $151.4 \pm 67.0$ \\
\hline $\operatorname{ALT}\left(\mathrm{U} \cdot \mathrm{L}^{-1}\right)$ & $56.6 \pm 7.7$ & $60.9 \pm 12.7$ & $90.0 \pm 26.1$ & $62.3 \pm 13.0$ \\
\hline Total protein $(\mathrm{g} / \mathrm{dL})$ & $6.5 \pm 0.6$ & $6.4 \pm 0.2$ & $6.8 \pm 0.3$ & $6.9 \pm 0.5$ \\
\hline Total bilirubin $\left(\mathrm{mg} \cdot \mathrm{dL}^{-1}\right)$ & $0.11 \pm 0.02$ & $0.07 \pm 0.04$ & $0.11 \pm 0.08$ & $0.05 \pm 0.04$ \\
\hline $\mathrm{BUN}\left(\mathrm{mg} \cdot \mathrm{dL}^{-1}\right)$ & $44.1 \pm 3.2$ & $43.9 \pm 4.1$ & $50.9 \pm 8.9$ & $48.6 \pm 8.6$ \\
\hline Creatinine $\left(\mathrm{mg} \cdot \mathrm{dL}^{-1}\right)$ & $0.6 \pm 0.2$ & $0.5 \pm 0.06$ & $0.4 \pm 0.1^{*}$ & $0.5 \pm 0.1$ \\
\hline$\delta-\mathrm{GT}\left(\mathrm{U} \cdot \mathrm{L}^{-1}\right)$ & $1.6 \pm 0.5$ & $1.7 \pm 0.7$ & $2.8 \pm 1.6$ & $1.4 \pm 0.7$ \\
\hline \multicolumn{5}{|c|}{ Female } \\
\hline Sodium $\left(\mathrm{mEq} \cdot \mathrm{L}^{-1}\right)$ & $132.7 \pm 6.0$ & $132.7 \pm 5.8$ & $132.4 \pm 2.6$ & $136.2 \pm 3.2$ \\
\hline Potassium $\left(\mathrm{mEq} \cdot \mathrm{L}^{-1}\right)$ & $6.8 \pm 1.1$ & $8.4 \pm 1.9$ & $8.6 \pm 1.4$ & $6.0 \pm 0.3$ \\
\hline Glucose $\left(\mathrm{mg} \cdot \mathrm{dL}^{-1}\right)$ & $116.6 \pm 22.9$ & $123.5 \pm 14.9$ & $119.5 \pm 17.1$ & $131.9 \pm 16.4$ \\
\hline Triglyceride $\left(\mathrm{mg} \cdot \mathrm{dL}^{-1}\right)$ & $99.9 \pm 20.6$ & $78.5 \pm 22.7$ & $58.9 \pm 12.5^{*}$ & $72.7 \pm 21.3^{*}$ \\
\hline Cholesterol $\left(\mathrm{mg} \cdot \mathrm{dL}^{-1}\right)$ & $98.4 \pm 13.3$ & $88.2 \pm 11.9$ & $92.0 \pm 19.5$ & $96.9 \pm 22.2$ \\
\hline Uric acid $\left(\mathrm{mg} \cdot \mathrm{dL}^{-1}\right)$ & $1.4 \pm 0.4$ & $1.8 \pm 0.8$ & $1.6 \pm 0.4$ & $1.1 \pm 0.5$ \\
\hline $\operatorname{ALP}\left(U \cdot L^{-1}\right)$ & $59.5 \pm 9.3$ & $57.8 \pm 13.6$ & $67.4 \pm 16.8$ & $54.5 \pm 19.1$ \\
\hline $\operatorname{AST}\left(\mathrm{U} \cdot \mathrm{L}^{-1}\right)$ & $173.4 \pm 71.9$ & $233.9 \pm 90.9$ & $193.5 \pm 58.6$ & $136.4 \pm 65.9$ \\
\hline $\operatorname{ALT}\left(\mathrm{U} \cdot \mathrm{L}^{-1}\right)$ & $59.0 \pm 12.9$ & $73.7 \pm 20.0$ & $68.5 \pm 14.9$ & $51.9 \pm 6.1$ \\
\hline Total protein $(\mathrm{g} / \mathrm{dL})$ & $7.4 \pm 0.8$ & $7.4 \pm 0.2$ & $7.9 \pm 0.5$ & $7.3 \pm 0.5$ \\
\hline Total bilirubin $\left(\mathrm{mg} \cdot \mathrm{dL}^{-1}\right)$ & $0.13 \pm 0.05$ & $0.15 \pm 0.08$ & $0.12 \pm 0.09$ & $0.13 \pm 0.05$ \\
\hline$\left(\mathrm{mg} \cdot \mathrm{dL}^{-1}\right)$ & $49.5 \pm 5.9$ & $59.3 \pm 12.7$ & $55.2 \pm 6.6$ & $45.3 \pm 6.8$ \\
\hline Creatinine $\left(\mathrm{mg} \cdot \mathrm{dL}^{-1}\right)$ & $0.6 \pm 0.2$ & $0.5 \pm 0.1$ & $0.5 \pm 0.1$ & $0.6 \pm 0.1$ \\
\hline$\delta-\mathrm{GT}\left(\mathrm{U} \cdot \mathrm{L}^{-1}\right)$ & $1.9 \pm 0.9$ & $3.3 \pm 1.4$ & $3.4 \pm 1.4$ & $2.5 \pm 0.9$ \\
\hline
\end{tabular}

The data are expressed as mean \pm SEM. ${ }^{*} P<0.05$, compared with control group (ANOVA or Kruskal-Wallis test).

The decrease in liver weight at doses of 4,000 and $5,000 \mathrm{mg} \cdot \mathrm{kg}^{-1}$ and tissue liver damage at a dose of $5,000 \mathrm{mg} \cdot \mathrm{kg}^{-1}$ indicate a direct action of the plant in the liver at high doses, which is consistent with Rebecca et al. $[23,24]$, who studied doses $>800 \mathrm{mg} \cdot \mathrm{kg}^{-1}$ in rats.

The high $\mathrm{LD}_{50}$ values of $\mathrm{F} 2\left(3,015 \mathrm{mg} \cdot \mathrm{kg}^{-1}\right)$ confirm its low acute toxicity that has been indicated by other parameters [39]. Moreover, Rebecca et al. [23] found an $\mathrm{LD}_{50}$ of $2,700 \mathrm{mg} \cdot \mathrm{kg}^{-1}$ of the crude extract with acute treatment, demonstrating that the aqueous fraction has less toxicity. The high $\mathrm{LD}_{50}$ values indicate that the extract can be administered with a high degree of safety.

In the repeated-dose oral toxicity experiment, no significant changes in behavior or mortality were observed in rats. According to Raza et al. [40], changes in body weight can indicate adverse effects when the animal shows a loss greater than $10 \%$ of initial weight. In the present study, however, neither group lost weight during treatment. At doses of 100 and $200 \mathrm{mg} \cdot \mathrm{kg}^{-1}$, significant differences in weight gain were observed.

According to Lewis et al. [41], "some factors can be useful in differentiating a significant change from control values, from a treatment-related effect. This difference is less likely to be an effect of treatment if: there is no obvious dose response; it is due to finding(s) in one or more animals that could be considered outlier(s) and it is within normal biological variation (within the range of reference values)."

In the present study, the biochemical results varied widely between doses and between sexes, with no linear profile. The altered values were within normal limits, and the results are considered normal for this animal species. Other values that changed did not show a dose response [42, 43].

In male rats, potassium, AST, and creatinine at $100 \mathrm{mg} \cdot \mathrm{kg}^{-1}$, triglycerides at $200 \mathrm{mg} \cdot \mathrm{kg}^{-1}$, and uric acid at 100 and $200 \mathrm{mg} \cdot \mathrm{kg}^{-1}$ significantly changed. In female rats, only triglycerides at 100 and $200 \mathrm{mg} \cdot \mathrm{kg}^{-1}$ significantly 
TABLE 5: Hematological results in male and female rats orally treated with F2 of S. adstringens for 90 days.

\begin{tabular}{|c|c|c|c|c|}
\hline \multirow{2}{*}{ Parameters } & \multirow{2}{*}{ Controls } & \multicolumn{3}{|c|}{$\mathrm{F} 2\left(\mathrm{mg} \cdot \mathrm{kg}^{-1}\right)$} \\
\hline & & 10 & 100 & 200 \\
\hline \multicolumn{5}{|c|}{ Male } \\
\hline $\begin{array}{l}\text { WBC } \\
\left(\times 10^{3} \mathrm{~mm}^{-3}\right)\end{array}$ & $10.6 \pm 3.7$ & $7.1 \pm 0.6$ & $8.7 \pm 2.8$ & $7.2 \pm 1.6$ \\
\hline Segmented (\%) & $20.9 \pm 8.9$ & $16.0 \pm 6.5$ & $15.9 \pm 4.9$ & $16.1 \pm 4.6$ \\
\hline Eosinophil (\%) & $2.3 \pm 0.8$ & $1.9 \pm 0.8$ & $1.5 \pm 0.5$ & $2.3 \pm 0.9$ \\
\hline $\begin{array}{l}\text { Lymphocyte } \\
(\%)\end{array}$ & $66.6 \pm 11.8$ & $75.2 \pm 9.7$ & $79.3 \pm 5.2$ & $78.6 \pm 5.6$ \\
\hline Monocyte (\%) & $3.4 \pm 0.7$ & $3.1 \pm 0.8$ & $3.1 \pm 0.5$ & $3.0 \pm 0.9$ \\
\hline $\begin{array}{l}\text { RBC } \\
\left(\times 10^{6} \mathrm{~mm}^{-3}\right)\end{array}$ & $8.16 \pm 0.3$ & $8.16 \pm 0.4$ & $8.22 \pm 0.5$ & $8.50 \pm 0.3$ \\
\hline $\begin{array}{l}\text { Haemoglobin } \\
(\mathrm{g} / \mathrm{dL})\end{array}$ & & $16.0 \pm 0.9$ & $16.4 \pm 1.1$ & $17.0 \pm 0.6$ \\
\hline $\begin{array}{l}\text { Haematocrit } \\
(\%)\end{array}$ & $46.7 \pm 1.8$ & $46.3 \pm 2.5$ & $46.5 \pm 3.2$ & $47.7 \pm 2.1$ \\
\hline MCV (fL) & $57.3 \pm 1.2$ & $56.7 \pm 1.2$ & $56.5 \pm 1.2$ & $55.9 \pm 1.4$ \\
\hline $\mathrm{MCH}(\mathrm{pg})$ & $20.9 \pm 0.5$ & $20.0 \pm 0.4^{*}$ & $19.9 \pm 0.5^{*}$ & $20.0 \pm 0.4^{*}$ \\
\hline $\mathrm{MCHC}(\%)$ & $36.5 \pm 0.7$ & $35.6 \pm 0.8$ & $35.1 \pm 0.3^{*}$ & $35.8 \pm 0.8$ \\
\hline $\begin{array}{l}\text { Platelet } \\
\left(\times 10^{3} \mathrm{~mm}^{-3}\right)\end{array}$ & & $929 \pm 108^{*}$ & $961 \pm 105^{*}$ & $895 \pm 106$ \\
\hline \multicolumn{5}{|c|}{ Female } \\
\hline $\begin{array}{l}\text { WBC } \\
\left(\times 10^{3} \mathrm{~mm}^{-3}\right)\end{array}$ & & $10.5 \pm 4.3$ & $8.3 \pm 2.6$ & $7.9 \pm 1.9$ \\
\hline Segmented (\%) & $18.2 \pm 8.0$ & $20.2 \pm 6.9$ & $14.3 \pm 4.3$ & $19.0 \pm 9.0$ \\
\hline Eosinophil (\%) & & $2.1 \pm 0.9$ & $2.2 \pm 0.9$ & $2.0 \pm 1.0$ \\
\hline $\begin{array}{l}\text { Lymphocyte } \\
(\%)\end{array}$ & $76.2 \pm 8.3$ & $74.3 \pm 8.0$ & $76.5 \pm 15.2$ & $75.6 \pm 10.3$ \\
\hline Monocyte (\%) & $3.2 \pm 0.8$ & $3.1 \pm 0.7$ & $2.9 \pm 0.8$ & $3.2 \pm 1.0$ \\
\hline $\begin{array}{l}\mathrm{RBC} \\
\left(\times 10^{6} \mathrm{~mm}^{-3}\right)\end{array}$ & $7.35 \pm 0.3$ & $7.27 \pm 0.6$ & $7.26 \pm 0.7$ & $7.5 \pm 0.4$ \\
\hline $\begin{array}{l}\text { Haemoglobin } \\
(\mathrm{g} / \mathrm{dL})\end{array}$ & $15.6 \pm 0.5$ & $15.3 \pm 1.2$ & $15.3 \pm 1.6$ & $15.8 \pm 0.9$ \\
\hline $\begin{array}{l}\text { Haematocrit } \\
(\%)\end{array}$ & $43.7 \pm 1.8$ & $42.9 \pm 3.9$ & $45.6 \pm 5.3$ & $44.6 \pm 2.4$ \\
\hline MCV (fL) & $59.5 \pm 1.1$ & $58.9 \pm 1.8$ & $59.9 \pm 1.9$ & $59.4 \pm 1.1$ \\
\hline $\mathrm{MCH}(\mathrm{pg})$ & $21.2 \pm 0.4$ & $21.0 \pm 0.5$ & $21.2 \pm 1.1$ & $21.1 \pm 0.3$ \\
\hline $\mathrm{MCHC}(\%)$ & $35.7 \pm 0.8$ & $35.6 \pm 1.3$ & $35.3 \pm 1.9$ & $35.7 \pm 0.5$ \\
\hline $\begin{array}{l}\text { Platelet } \\
\left(\times 10^{3} \mathrm{~mm}^{-3}\right)\end{array}$ & $878 \pm 124$ & $884 \pm 187$ & $856 \pm 168$ & $730 \pm 202$ \\
\hline
\end{tabular}

The data are expressed as mean \pm SEM. ${ }^{*} P<0.05$, compared with control group (ANOVA or Kruskal-Wallis test).

changed compared with the control group. To evaluate kidney function, creatinine, urea, sodium, potassium, and uric acid were assessed [44]. Urea and sodium were not different from controls in both female and male rats. In males, significant differences in creatinine and potassium levels in the groups treated with F2 did not show a dose response, and uric acid remained within the normal range $\left(1.2-7.5 \mathrm{mg} \cdot \mathrm{dL}^{-1}\right)$ [42]. The same parameters also did not change in females. This suggests that F2 does not adversely affect kidney function, confirmed by the absence of histopathological changes in this organ.

To evaluate liver function, AST, ALT, ALP, total bilirubin, and $\gamma$-GT were assessed because these are considered markers of liver function, and liver changes have been reported after phytotherapeutic product use [45-48]. In the present study, a significant increase in AST levels was only observed in male rats at the intermediate dose, with no dose response. As noted earlier, the high doses used in the acute study altered liver tissue, which could justify the increase in AST through the release of enzymes from the cells of the damaged organ or changes in cellular membrane permeability [23]. However, this did not appear to be the case at present. Our histopathological examinations did not indicate any cellular lesions.

The levels of total protein, glucose, cholesterol, and triglycerides were measured to assess the general biochemical profile of the animals and determine the presence of metabolic changes. The values were not significantly different between the control and treatment groups in both female and male rats, with the exception of triglycerides, which appeared to be reduced in both females and males but remained within the normal range [43]. High doses of the crude extract of stem bark can cause liver mitochondrion toxicity $[23,24]$. Mitochondrial lesions can alter lipid metabolism.

In the present study, hematological changes did not appear to be related to treatment with F2. No changes were observed in females, but changes in $\mathrm{MCH}(10,100$, and $\left.200 \mathrm{mg} \cdot \mathrm{kg}^{-1}\right)$, MCHC (100 mg. $\left.\mathrm{kg}^{-1}\right)$, and platelet counts (10 and $100 \mathrm{mg} \cdot \mathrm{kg}^{-1}$ ) were observed in males. However, the changes in MCHC and platelets did not show a dose-response relationship, and the changes in $\mathrm{MCH}$, despite being evident at the three doses tested, remained within the normal range $(19.0 \pm 1.09)$ [43]. These results suggest that F2 did not exert effects on blood cells or bone marrow, which are both sensitive to toxicity in animals [49]. This result is supported by the absence of F2 genotoxicity in mice in another study [28].

The relative weights of the organs did not show significant changes in the macroscopic and histopathological examinations in the treatment groups compared with controls in either sex. In contrast to the study by Rebecca et al. [23], which found thymus involution at high doses, lower doses did not affect this organ.

Another interesting result was found in the open-field test, in which none of the parameters showed significant changes, indicating that F2 did not exert neurobehavioral alterations in the animals.

The low toxicity of F2 from the stem bark of $S$. adstringens, reflected by high $\mathrm{LD}_{50}$ values, suggests a wide safety margin at therapeutic doses. In the repeated-dose oral toxicity study, no serious signs or significant changes in hematological, biochemical, and histopathological parameters or other remarkable effects were observed in rats. These toxicity studies suggest that the fraction is safe at the doses administered. However, further studies are needed to evaluate other parameters, including carcinogenicity, teratogenicity, and 
neurotoxicity. Future clinical pharmacology studies should also be conducted to determine tolerance and substantiate its pharmacological use.

\section{Conclusions}

The low toxicity of F2 obtained from stem bark of S. adstringens in the acute and repeated-dose oral (chronic) toxicity studies suggests that F2 obtained from the stem bark of $S$. adstringens is safe at the concentrations tested.

\section{Glossary}

F1: Crude extract obtained from the stem bark of Stryphnodendron adstringens

F2: Aqueous fraction obtained from the stem bark of Stryphnodendron adstringens

$\mathrm{LD}_{50}$ : Dose that inactivates $50 \%$ of individuals.

\section{Conflict of Interests}

The authors declare that there is no conflict of interests.

\section{Acknowledgments}

The authors thank Maristela Gabriel for technical assistance. This study was supported by CAPES, CNPQ, FINEP, and PRONEX/Fundação Araucária.

\section{References}

[1] S. C. Udem, O. Obidoa, and I. U. Asuzu, "Acute and chronic toxicity studies of Erythrina senegalensis DC stem bark extract in mice," Comparative Clinical Pathology, vol. 19, no. 3, pp. 275282, 2010 .

[2] G. K. Singh and V. Kumar, "Acute and sub-chronic toxicity study of standardized extract of Fumaria indica in rodents," Journal of Ethnopharmacology, vol. 134, no. 3, pp. 992-995, 2011.

[3] J. B. Calixto, "Efficacy, safety, quality control, marketing and regulatory guidelines for herbal medicines (phytotherapeutic agents)," Brazilian Journal of Medical and Biological Research, vol. 33, no. 2, pp. 179-189, 2000.

[4] U. P. de Albuquerque, J. M. Monteiro, M. A. Ramos, and E. L. C. de Amorim, "Medicinal and magic plants from a public market in northeastern Brazil," Journal of Ethnopharmacology, vol. 110, no. 1, pp. 76-91, 2007.

[5] A. C. C. Sanches, G. C. Lopes, C. E. M. Toledo, L. V. S. Sacramento, C. M. Sakuragui, and J. C. P. Mello, "Estudo Morfológico Comparativo das Cascas e Folhas de Stryphnodendron adstringens, S. polyphyllum e S. obovatum- Leguminosae," Latin American Journal of Pharmacy, vol. 26, no. 3, pp. 362-368, 2007.

[6] G. C. Lopes, A. C. C. Sanches, C. V. Nakamura, B. P. Dias Filho, L. Hernandes, and J. C. P. De Mello, "Influence of extracts of Stryphnodendron polyphyllum Mart. and Stryphnodendron obovatum Benth. on the cicatrisation of cutaneous wounds in rats," Journal of Ethnopharmacology, vol. 99, no. 2, pp. 265-272, 2005.

[7] M. D. F. Agra, K. N. Silva, I. J. L. D. Basílio, P. F. De Freitas, and J. M. Barbosa-Filho, "Survey of medicinal plants used in the region Northeast of Brazil," Brazilian Journal of Pharmacognosy, vol. 18, no. 3, pp. 472-508, 2008.

[8] M. G. Brandão, N. N. Zanetti, P. Oliveira, C. F. Grael, A. C. Santos, and R. L. M. Monte-Mór, "Brazilian medicinal plants described by 19th century European naturalists and in the Official Pharmacopoeia," Journal of Ethnopharmacology, vol. 120, no. 2, pp. 141-148, 2008.

[9] Z. V. Pereira, R. M. Mussury, A. B. de Almeida, and A. Sangalli, "Medicinal plants used by Ponta Porã community, Mato Grosso do Sul State," Acta Scientiarum-Biological Sciences, vol. 31, no. 3, pp. 293-299, 2009.

[10] E. A. Audi, D. P. Toledo, P. G. Peres et al., "Gastric antiulcerogenic effects of Stryphnodendron adstringens in rats," Phytotherapy Research, vol. 3, pp. 264-266, 1999.

[11] E. A. Audi, C. E. Mendes De Toledo, F. Solera Dos Santos et al., "Biological activity and quality control of extract and stem bark from Stryphnodendron adstringens," Acta Farmaceutica Bonaerense, vol. 23, no. 3, pp. 328-333, 2004.

[12] J. D. Herzog-Soares, R. K. Alves, E. Isac et al., "Atividade tripanocida in vivo de Stryphnodendron adstringens (barbatimão verdadeiro) e Caryocar brasiliensis (pequi)," Revista Brasileira de Farmacognosia, vol. 12, pp. 1-2, 2002.

[13] P. S. Luize, T. S. Tiuman, L. G. Morello et al., "Effects of medicinal plant extracts on growth of Leishmania (L.) amazonensis and Trypanosoma cruzi," Brazilian Journal of Pharmaceutical Sciences, vol. 41, no. 1, pp. 85-94, 2005.

[14] F. B. Holetz, T. Ueda-Nakamura, B. P. Dias Filho et al., "Biological effects of extracts obtained from Stryphnodendron adstringens on Herpetomonas samuelpessoai," Memorias do Instituto Oswaldo Cruz, vol. 100, no. 4, pp. 397-401, 2005.

[15] A. M. M. Felipe, V. P. Rincão, F. J. Benati et al., "Antiviral effect of Guazuma ulmifolia and Stryphnodendron adstringens on poliovirus and bovine herpesvirus," Biological and Pharmaceutical Bulletin, vol. 29, no. 6, pp. 1092-1095, 2006.

[16] K. Ishida, J. C. Palazzo de Mello, D. A. Garcia Cortez, B. P. Dias Filho, T. Ueda-Nakamura, and C. V. Nakamura, "Influence of tannins from Stryphnodendron adstringens on growth and virulence factors of Candida albicans," Journal of Antimicrobial Chemotherapy, vol. 58, no. 5, pp. 942-949, 2006.

[17] K. Ishida, S. Rozental, J. C. P. de Mello, and C. V. Nakamura, "Activity of tannins from Stryphnodendron adstringens on Cryptococcus neoformans: effects on growth, capsule size and pigmentation," Annals of Clinical Microbiology and Antimicrobials, vol. 8, p. 29, 2009.

[18] T. M. De Souza, J. A. Severi, V. Y. A. Silva, E. Santos, and R. C. L. R. Pietro, "Bioprospection of antioxidant and antimicrobial activities in the bark of Stryphnodendron adstringens (Mart.) Coville (Leguminosae-Mimosoidae)," Revista de Ciencias Farmaceuticas Basica e Aplicada, vol. 28, no. 2, pp. 221-226, 2007.

[19] J. Palazzo De Mello, F. Petereit, and A. Nahrstedt, "Flavan3-ols and prodelphinidins from Stryphnodendron adstringens," Phytochemistry, vol. 41, no. 3, pp. 807-813, 1996.

[20] J. Palazzo De Mello, F. Petereit, and A. Nahrstedt, "Prorobinetinidins from Stryphnodendron adstringens," Phytochemistry, vol. 42, no. 3, pp. 857-862, 1996.

[21] J. C. Palazzo De Mello, F. Petereit, and A. Nahrstedt, "A dimeric proanthocyanidin from Stryphnodendron adstringens," Phytochemistry, vol. 51, no. 8, pp. 1105-1107, 1999.

[22] G. C. Lopes, F. A. Vieira Machado, C. E. Mendes de Toledo, C. M. Sakuragui, and J. C. Palazzo de Mello, "Chemotaxonomic significance of 5-deoxyproanthocyanidins in Stryphnodendron 
species," Biochemical Systematics and Ecology, vol. 36, no. 12, pp. 925-931, 2008.

[23] M. A. Rebecca, E. L. Ishii-Iwamoto, R. Grespan et al., "Toxicological studies on Stryphnodendron adstringens," Journal of Ethnopharmacology, vol. 83, no. 1-2, pp. 101-104, 2002.

[24] M. A. Rebecca, E. L. Ishii-Iwamoto, A. M. Kelmer-Bracht et al., "Effect of Stryphnodendron adstringens (barbatimão) on energy metabolism in the rat liver," Toxicology Letters, vol. 143, no. 1, pp. 55-63, 2003.

[25] M. E. Bürger, N. Ahlert, B. Baldisserotto, A. Langeloh, B. Schirmer, and R. Foletto, "Analysis of the abortive and/or infertilizing activity of Stryphnodendron adstringens (Mart.) Coville," Brazilian Journal of Veterinary Research and Animal Science, vol. 36, pp. 296-299, 1999.

[26] P. Cintra, O. Malaspina, and O. C. Bueno, "Toxicity of barbatimão to Apis mellifera and Scaptotrigona postica, under laboratory conditions," Journal of Apicultural Research, vol. 42, no. 1-2, pp. 9-12, 2003.

[27] N. C. De Sousa, S. De Carvalho, M. A. Spanó, and U. Graf, "Absence of genotoxicity of a phytotherapeutic extract from Stryphnodendron adstringens (Mart.) Coville in somatic and germ cells of Drosophila melanogaster," Environmental and Molecular Mutagenesis, vol. 41, no. 4, pp. 293-299, 2003.

[28] M. A. Costa, K. Ishida, V. Kaplum et al., "Safety evaluation of proanthocyanidin polymer-rich fraction obtained from stem bark of Stryphnodendron adstringens (Barbatimão) for use as a pharmacological agent," Regulatory Toxicology and Pharmacology, vol. 58, no. 2, pp. 330-335, 2010.

[29] Brasil. Ministério da Saúde. Anvisa-Agência Nacional de Vigilância Sanitária, "Resolução RDC n 48 . Dispõe sobre o registro de medicamentos fitoterápicos," 2004.

[30] Brasil. Ministério da Saúde. Anvisa-Agência Nacional de Vigilância Sanitária, "Resolução-RE n90. Guia para a realização de estudos de Toxicidade Pré-Clínica de Fitoterápicos," 2004.

[31] T. M. Antonelli-Ushirobira, E. N. Kaneshima, M. Gabriel, E. A. Audi, L. C. Marques, and J. C. P. Mello, "Acute and subchronic toxicological evaluation of the semipurified extract of seeds of guaraná (Paullinia cupana) in rodents," Food and Chemical Toxicology, vol. 48, no. 7, pp. 1817-1820, 2010.

[32] C.-Y. Li, R. K. Devappa, J.-X. Liu, J.-M. Lv, H. P. S. Makkar, and K. Becker, "Toxicity of Jatropha curcas phorbol esters in mice," Food and Chemical Toxicology, vol. 48, no. 2, pp. 620-625, 2010.

[33] L. C. Miller and M. L. Tainter, "Estimation of the ED50 and its error by means of logarithmic probit graph paper," Proceedings of the society for Experimental Biology and Medicine, vol. 57, pp. 261-264, 1994.

[34] Plantas que Curam, 2013, http://www.plantasquecuram.com .br/ervas/barbatimao.html.

[35] J. R. Royce, "On the construct validity of open-field measures," Psychological Bulletin, vol. 84, no. 6, pp. 1098-1106, 1977.

[36] F. C. Odds, A. J. P. Brown, and N. A. R. Gow, "Antifungal agents: mechanisms of action," Trends in Microbiology, vol. 11, no. 6, pp. 272-279, 2003.

[37] P. L. Fidel Jr., "History and update on host defense against vaginal candidiasis," American Journal of Reproductive Immunology, vol. 57, no. 1, pp. 2-12, 2007.

[38] L. Ostrosky-Zeichner, "Combination antifungal therapy: a critical review of the evidence," Clinical Microbiology and Infection, vol. 14, no. 4, pp. 65-70, 2008.
[39] T. A. Loomis and A. W. Hayes, Loomis Essentials of Toxicology, Academic Press, New York, NY, USA, 1996.

[40] M. Raza, O. A. Al-Shabanah, T. M. El-Hadiyah, and A. A. AlMajed, "Effect of prolonged vigabatrin treatment on hematological and biochemical parameters in plasma, liver and kidney of Swiss albino mice," Scientia Pharmaceutica, vol. 70, no. 2, pp. 135-145, 2002.

[41] R. W. Lewis, R. Billington, E. Debryune, A. Gamer, B. Lang, and F. Carpanini, "Recognition of adverse and nonadverse effects in toxicity studies," Toxicologic Pathology, vol. 30, no. 1, pp. 66-74, 2002.

[42] B. M. Mitruka and H. M. Rawnsley, "Clinical biochemical and hematological reference values," in Normal Experimental Animals, Masson Publishing, New York, NY, USA, 1977.

[43] S. T. Wolford, R. A. Schroer, F. X. Gohs et al., "Reference range data base for serum chemistry and hematology values in laboratory animals," Journal of Toxicology and Environmental Health, vol. 18, no. 2, pp. 161-188, 1986.

[44] G. Chandramohan, K. S. Al-Numair, and K. V. Pugalendi, "Effect of 3-hydroxymethyl xylitol on hepatic and renal functional markers and protein levels in streptozotocindiabetic rats," African Journal of Biochemistry Research, vol. 3, pp. 198-204, 2009.

[45] C. M. Corns, "Herbal remedies and clinical biochemistry," Annals of Clinical Biochemistry, vol. 40, no. 5, pp. 489-507, 2003.

[46] J. El Hilaly, Z. H. Israili, and B. Lyoussi, "Acute and chronic toxicological studies of Ajuga iva in experimental animals," Journal of Ethnopharmacology, vol. 91, no. 1, pp. 43-50, 2004.

[47] S. O. Aniagu, F. C. Nwinyi, B. Olanubi et al., "Is Berlina grandiflora (Leguminosae) toxic in rats?" Phytomedicine, vol. 11, no. 4, pp. 352-360, 2004.

[48] M.-F. Yuen, Y. Tanaka, D. Y.-T. Fong et al., "Independent risk factors and predictive score for the development of hepatocellular carcinoma in chronic hepatitis B," Journal of Hepatology, vol. 50, no. 1, pp. 80-88, 2009.

[49] H. A. Harper, Review of Physiological Chemistry, Lange Medical Publications, Los Altos, Calif, USA, 14th edition, 1973. 


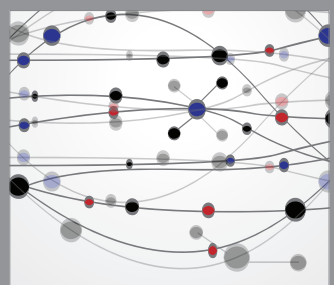

The Scientific World Journal
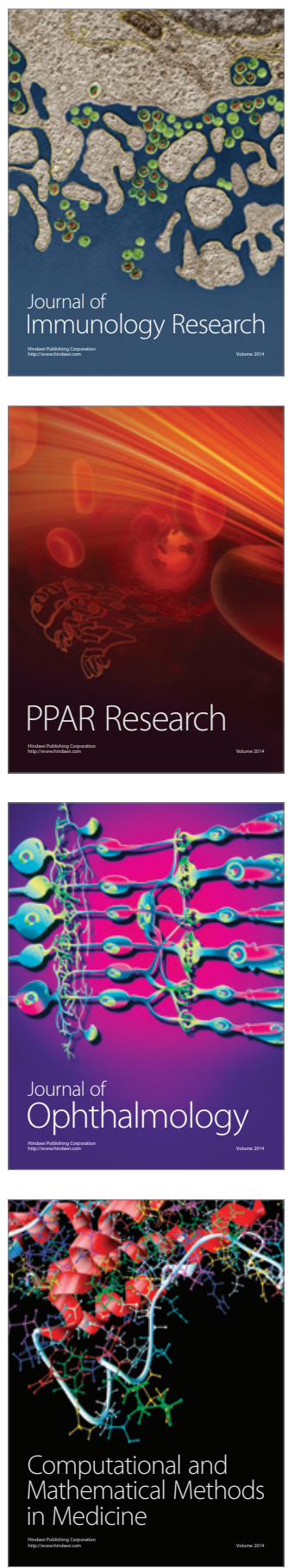

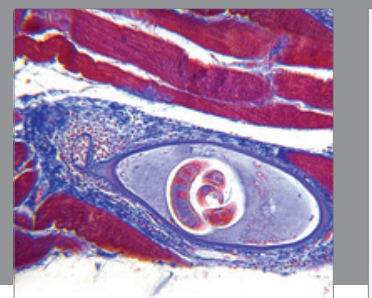

Gastroenterology

Research and Practice
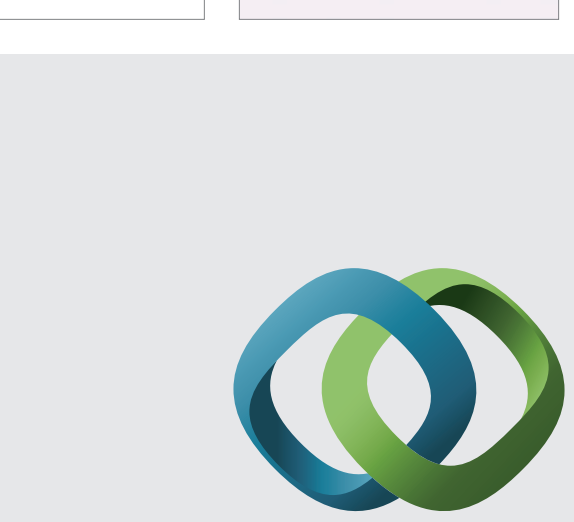

\section{Hindawi}

Submit your manuscripts at

http://www.hindawi.com
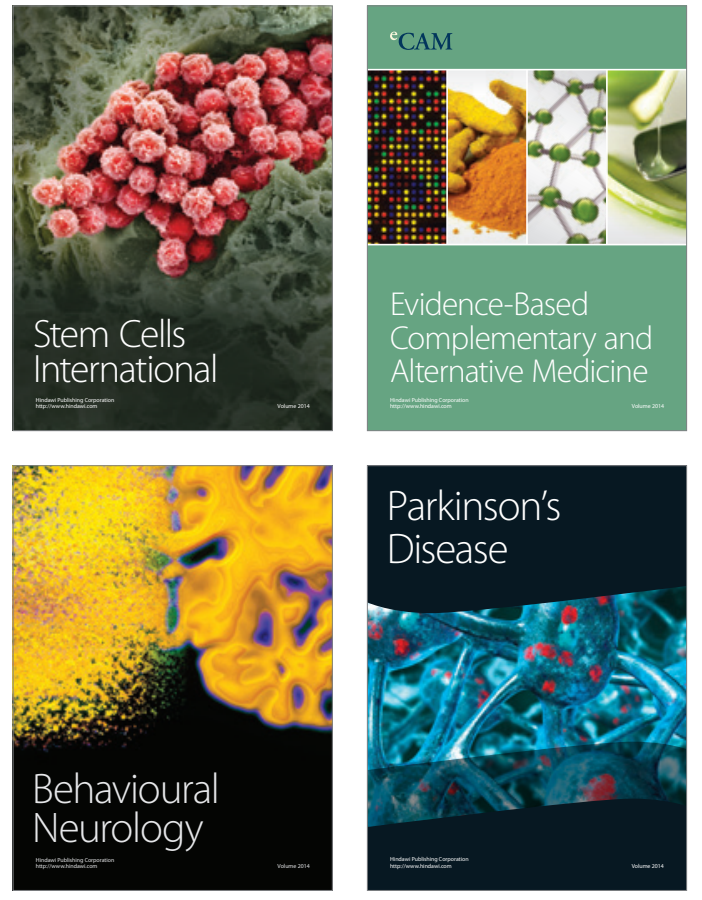
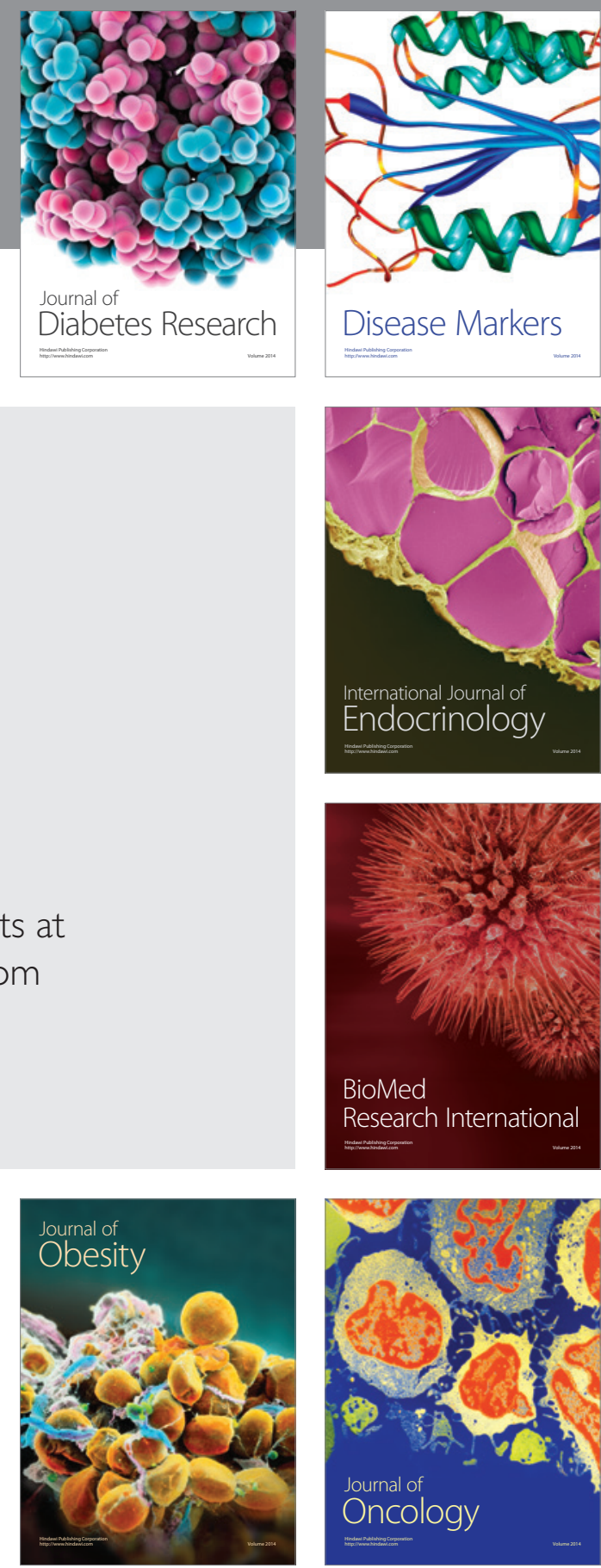

Disease Markers
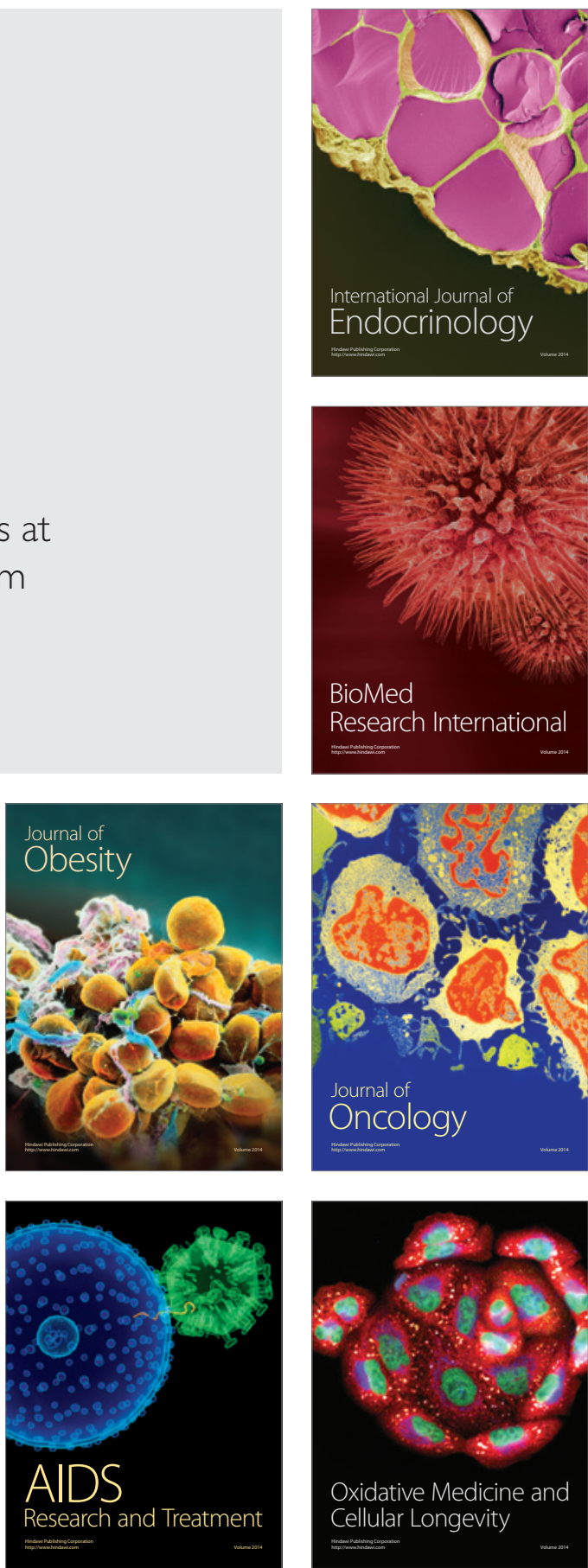